\title{
EDITORIAL
}

\section{INTERNACIONALIZACIÓN DE REVISTAS CIENTÍFICAS EN CAMPOS EMERGENTES COMO ANTROPOLOGÍA: DESAFÍOS Y OPORTUNIDADES PARA CHUNGARA}

\author{
INTERNATIONALIZATION OF SCIENTIFIC JOURNALS IN EMERGING \\ FIELDS SUCH AS ANTHROPOLOGY: CHALLENGES \\ AND OPPORTUNITIES FOR CHUNGARA
}

\author{
Calogero M. Santoro ${ }^{1,2}$, Vivien G. Standen ${ }^{3}$, Dante Angelo ${ }^{3}$ y Vivian Gavilán ${ }^{3}$
}

Este número marca el inicio de la transición hacia una nueva era de Chungara, luego de varios años de encomiable esfuerzo y duro trabajo por parte del equipo editorial liderado por Calogero Santoro, Vivien Standen y anteriores editores, como Jorge Hidalgo, para que Chungara sea hoy reconocida como una de las revistas de antropología más importantes de Sudamérica. Estos logros han superado con creces las expectativas iniciales, lo que da un buen pie para resolver los desafíos globales que enfrentan las revistas científicas. El recuento de los 40 años de Chungara celebrados durante el XIX Congreso Nacional de Arqueología Chilena (Santoro y Standen 2012), permitió reconocer la necesidad de definir un plan estratégico para consolidar Chungara como foro internacional de difusión de ideas e innovación orientada a un público especializado y general.

En ese sentido, uno de los pasos más importantes para la Revista tiene que ver con su condición de libre accesibilidad en la web, abriendo la opción de ser consultada mundialmente. Hoy en día, con un avance exponencial del conocimiento científico y una necesidad de exponer y discutir ideas innovadoras, uno de los desafíos centrales es la apertura democrática de acceso a la información, como lo vienen certificando los esfuerzos de grupos como SciELO y otras plataformas en las que la Revista está listada (Santoro y Standen 2012).

El desafío de expandir la red internacional implica mejorar la calidad de los manuscritos seleccionados, conseguir un mayor flujo de manuscritos especializados de corriente principal, o de cobertura
The present issue marks the beginning of the transition to a new era for Chungara. After several years of praiseworthy effort and hard work by the editorial team led by Calogero Santoro, Vivien Standen and former editors such as Jorge Hidalgo, Chungara is now recognized as one of the most important anthropology journals of South America. These achievements have exceeded our original expectations, and provide a firm basis to deal with the global challenges faced by scientific journals today. Reviewing the 40 years of Chungara during the $12^{\text {th }}$ National Congress of Chilean Archaeology (Santoro and Standen 2012) led to an acknowledgment of the need for a strategic plan in order to consolidate Chungara as an international forum to spread ideas and innovation among both specialized and general audiences.

In this regard, one of the most important steps for the Journal has been its open access, thanks to which it can be consulted worldwide. Today, with the exponential growth of scientific knowledge and the need to expose and discuss innovative ideas, one of the central challenges concerns the democratic access to information, as evidenced by the efforts of groups such as SciELO and other online platforms in which the Journal is listed (Santoro and Standen 2012).

The challenge of expanding the international network implies raising the quality of the selected manuscripts, getting a greater flow of mainstream specialized manuscripts, or ones of more global geographical coverage as well as emerging themes including authors with international scientific

\footnotetext{
Instituto de Alta Investigación, Universidad de Tarapacá, Arica, Chile. calogero_santoro@yahoo.com Centro de Investigaciones del Hombre en el Desierto (CIHDE), Arica, Chile.

Departamento de Antropología, Universidad de Tarapacá, 18 de Septiembre 2222, Casilla 6D, Arica, Chile. vstanden@chungara.cl; dangeloz@uta.cl; viviangav@yahoo.com
} 
geográfica más global, o de temas emergentes que incluyan autores con redes científicas internacionales. Adicionalmente, es necesario superar las fragilidades en la gestión editorial integrando un cuerpo de editores asociados internacionales, mantener procesos rigurosos y transparentes de evaluación con revisores internacionales.

Es necesario también disminuir el tiempo promedio de evaluación y edición de los manuscritos, mantener la periodicidad, puntualidad y calidad de las ediciones y aplicar el sistema de publicación digital anticipada (early view) de los artículos para darlos a conocer con anticipación a la publicación y definir políticas de acción de marketing (Abel Packer comunicación personal junio, 2013). Esta nueva era de Chungara será liderada por una renovada estructura organizacional que incluye un editor en jefe, Vivien G. Standen, y tres editores de sección, a saber: bioantropología encabezada igualmente por la editora en jefe, antropología e historia encabezada por Vivian Gavilán y arqueología y patrimonio encabezada por Dante Angelo. Estos a su vez tendrán una contraparte de editores internacionales en cada línea disciplinaria.

La aplicación de estas medidas a la gestión de Chungara permitirá, entre otros resultados, superar debilidades propias de Revistas emergentes (Abel Packer, comunicación personal) y contribuir a levantar sus índices de impacto, una de las maneras más duras de medir la visualización internacional. Actualmente, contamos con valoraciones bibliométricas en la Web of Science de Thomson Reuters/ Scientific, como así también de Scopus y SciELO que es necesario mejorar. A partir del año 2005, que Chungara quedó indizada en Thomson Reuters/ Scientific, hemos tenido un importante aumento de autores internacionales y se ha ampliado la cobertura geográfica al recibir contribuciones de estudios antropológicos de toda Latinoamérica y España. No obstante lo anterior, la Revista se ha mantenido con índices de impacto intermedios.

Recientemente, Alberts (2013) Editor-in-Chief of Science, ha señalado "The impact factor, a number calculated annually for each scientific journal based on the average number of times its articles have been referenced in other articles" ha sido mal usado en la medida que se ha aplicado para rankear a los propios científicos, lo que ha generado según Alberts una depreciación hacia revistas de campos científicos con bajo número de participantes, entre las que cita específicamente a las ciencias sociales networks. It is also necessary to strengthen the editorial management by integrating a board of international associate editors and to maintain rigorous and transparent peer review processes with international reviewers.

Other necessary changes include reducing the average time of review and editing of the manuscripts, keeping regularity, punctuality and quality of the issues and implementing the early view system, so papers can be read online before publication, as well as setting up marketing policies (Abel Packer, personal communication, June 2013). This new era in Chungara will be led by a renovated organizational structure including an Editor-in-Chief, Vivien G. Standen, and three section editors: Bioanthropology, in charge of the Editor-in-Chief, anthropology and history, in charge of Vivian Gavilán, and archaeology and heritage, in charge of Dante Angelo. They will also have a group of international editors for each disciplinary line.

These measures in the management of Chungara will allow the journal, among other things, to overcome typical weaknesses of emerging Journals (Abel Packer, personal communication) and will contribute to raising its impact factors, which is solid proof of international visibility. We currently have bibliometric valuations in Thomson Reuters/ Scientific Web of Science, as well as in Scopus and SciELO, which need to be improved. As of 2005, when Chungara was indexed in Thomson Reuters/Scientific, the number of submissions by international authors has increased and the geographical coverage has broadened by the submission of anthropological studies from all of Latin America and Spain. In spite of this, the Journal has maintained intermediate impact factors.

Recently, Alberts (2013), Editor-in-Chief of Science, has pointed out that "the impact factor, a number calculated annually for each scientific journal based on the average number of times its articles have been referenced in other articles" has been misused to rank scientists themselves, which, according to Alberts, has resulted in the devaluation of journals of scientific fields with few participants, among which he specifically identifies the social sciences and ecology, whose specialized journals are stigmatized and unable to improve their impact factors as they are less cited.

Another consequence of this, Alberts claims, is that higher impact journals, like the one he runs, are overwhelmed with a number of "inappropriate 
y ecología, cuyas revistas especializadas se ven estigmatizadas e imposibilitadas de mejorar sus índices de impacto porque son menos citadas.

Otra consecuencia de esto, reclama Alberts, es que las revistas de alto impacto, como la que él dirige, se han visto sobrepasadas por el envío de "inappropiate submissions from researchers who are desperate to gain point from their evaluators". Este sistema favorece, también, a las áreas de investigación con mayor número de investigadores, lo cual según Alberts "creates a strong disincentive to pursue risky and potentially groundbreaking work, because it takes years to create a new approach in a new experimental context, during which no publication should be expected". Más aún estas valoraciones bibliométricas desincentivan la innovación en la medida en que resulta más atractivo y "efectivo" trabajar en campos disciplinarios constituidos por un gran universo de investigadores, lo que asegura un mayor número de citas independientemente de la calidad de la investigación. En ese contexto Alberts concluye que en algunos campos, sólo los científicos más osados se atreverán a explorar áreas de la investigación pobremente poblados "unless automated numerical evaluations of individuals are eliminated".

Expandiendo el análisis crítico de Alberts, estimamos que revistas como Chungara tienen una tremenda oportunidad para generar espacios para la publicación de los mejores trabajos no sólo de los campos tradicionales de la antropología, sino también de nuevas áreas temáticas de la disciplina. De esta manera, podemos contribuir a corregir el efecto destructivo, señalado por Alberts en el desarrollo de las ciencias en general por el mal uso del índice de impacto de las Revistas. submissions from researchers who are desperate to gain points from their evaluators". The system also favors research areas with a greater number of researchers, which, according to Alberts, "creates a strong disincentive to pursue risky and potentially groundbreaking work, because it takes years to create a new approach in a new experimental context, during which no publication should be expected". Even more, this bibliometric valuations discourage innovation as it is more appealing and "effective" to work in disciplinary fields with a great universe of researchers, which guarantees a larger number of references regardless the quality of the research. In that context, Alberts concludes that, in some fields, only the boldest scientists will dare explore less populated areas of research "unless automated numerical evaluations of individuals are eliminated".

Expanding on Alberts' critical analysis, we believe that journals like Chungara have a tremendous opportunity to create spaces for the publication of the best works not only in the traditional areas of anthropology but also in new themes of the discipline. Thus, we can contribute to correct the destructive effect pointed out by Alberts in the development of sciences in general as a result of the misuse of journals impact factor.

\section{Referencias Citadas}

Alberts, B. 2013. Impact factor distortions. Science 340: 786-787.
Santoro, C.M. y V.G. Standen 2012. Cuarenta años de difusión científica de Chungara. Chungara Revista de Antropología Chilena 44:3-8. 
